\title{
Defucosylated anti-CCR4 monoclonal antibody exercises potent ADCC-mediated antitumor effect in the novel tumor-bearing humanized NOD/Shi-scid, IL-2R $\gamma^{\text {null }}$ mouse model
}

\author{
Asahi Ito $\cdot$ Takashi Ishida $\cdot$ Hiroki Yano $\cdot$ Atsushi Inagaki $\cdot$ Susumu Suzuki $\cdot$ Fumihiko Sato \\ Hisashi Takino · Fumiko Mori • Masaki Ri • Shigeru Kusumoto · Hirokazu Komatsu • \\ Shinsuke Iida $\cdot$ Hiroshi Inagaki $\cdot$ Ryuzo Ueda
}

Received: 20 September 2008 / Accepted: 12 November 2008 / Published online: 2 December 2008

(c) The Author(s) 2008. This article is published with open access at Springerlink.com

\begin{abstract}
Purpose There are no suitable small animal models to evaluate human antibody-dependent cellular cytotoxicity (ADCC) in vivo, due to species incompatibilities. Thus, the first aim of this study was to establish a human tumor-bearing mouse model in which human immune cells can engraft and mediate $\mathrm{ADCC}$, but where the endogenous mouse immune cells cannot mediate ADCC. The second aim was to evaluate ADCC mediated in these humanized mice by the defucosylated anti-CC chemokine receptor 4 (CCR4) monoclonal antibody (mAb) which we have developed and which is now in phase I clinical trials.

Experimental design NOD/Shi-scid, IL-2R $\gamma^{\text {null }}$ (NOG) mice were the recipients of human immune cells, and CCR4-expressing Hodgkin lymphoma (HL) and cutaneous T-cell lymphoma (CTCL) cell lines were used as target tumors.

Results Humanized mice have been established using NOG mice. The chimeric defucosylated anti-CCR4 mAb KM2760 showed potent antitumor activity mediated by robust $\mathrm{ADCC}$ in these humanized mice bearing the HL or CTCL cell lines. KM2760 significantly increased the
\end{abstract}

A. Ito $\cdot$ T. Ishida $(\square) \cdot$ H. Yano $\cdot$ A. Inagaki $\cdot$ S. Suzuki $\cdot$

F. Mori $\cdot$ M. Ri $\cdot$ S. Kusumoto $\cdot$ H. Komatsu $\cdot$ S. Iida $\cdot$ R. Ueda Department of Medical Oncology and Immunology,

Nagoya City University Graduate School of Medical Sciences, 1 Kawasumi, Mizuho-chou, Mizuho-ku,

Nagoya, Aichi 467-8601, Japan

e-mail: itakashi@med.nagoya-cu.ac.jp

F. Sato $\cdot$ H. Takino $\cdot$ H. Inagaki

Department of Clinical Pathology,

Nagoya City University Graduate School of Medical Sciences,

1 Kawasumi, Mizuho-chou, Mizuho-ku,

Nagoya, Aichi 467-8601, Japan number of tumor-infiltrating CD56-positive NK cells which mediate ADCC, and reduced the number of tumor-infiltrating FOXP3-positive regulatory $\mathrm{T}$ (Treg) cells in HL-bearing humanized mice.

Conclusions Anti-CCR4 mAb could be an ideal treatment modality for many different cancers, not only to directly kill CCR4-expressing tumor cells, but also to overcome the suppressive effect of Treg cells on the host immune response to tumor cells. In addition, using our humanized mice, we can perform the appropriate preclinical evaluation of many types of antibody based immunotherapy.

Keywords NOD/Shi-scid $\cdot$ IL-2R $\gamma^{\text {null }}$ mice $\cdot$ ADCC . $\mathrm{CCR} 4 \cdot \mathrm{NK}$ cell $\cdot$ Regulatory $\mathrm{T}$ cell

\section{Introduction}

The use of therapeutic monoclonal antibody (mAb) for the treatment of cancer has evolved into a promising approach over the last several years [1-6]. Antibodies of the human IgG1 isotype are commonly used for therapeutic applications as they can mediate multiple effector functions including antibody-dependent cellular cytotoxicity (ADCC), complement-dependent cytotoxicity (CDC), and direct apoptosis induction [7-9]. Of these, ADCC is an especially important mechanism of action of therapeutic mAb against tumor cells [10-13]; therefore, a better understanding of ADCC will allow the development of novel, more effective treatment strategies using therapeutic mAbs. ADCC depends on the cytotoxic activity of immune effector cells, so to evaluate antitumor effects of therapeutic mAb in a small animal model in vivo, the species incompatibility of the immune system between humans and animals is a critical issue. Indeed, we have previously reported that the 
mouse effector system mediating the antitumor action of therapeutic mAb does differ from the human $[14,15]$. Thus, a current crucial problem in the field of human ADCC research is the lack of suitable small animal models. To overcome this, we attempted to establish "humanized mice", in which human immune cells could mediate the antitumor action of the therapeutic mAb. In order to construct such "humanized mice", here we tested NOD/ Shi-scid, IL-2R $\gamma^{\text {null }}$ (NOG) mice as recipients of human immune cells, because it has been reported that these mice have multiple immune dysfunctions, and that human immune cells can be engrafted in NOG mice and retain almost the same functions as in humans [16, 17].

In the clinical field of hematological malignancies, the development of the therapeutic mAb rituximab has changed the standard therapy in patients with B-cell lymphomas [1, 2], and has markedly improved their prognosis. In contrast, T-cell lymphomas have very poor prognoses, and no standard treatment strategies for these diseases have been developed so far [18]. Because we previously found that CC chemokine receptor 4 (CCR4) is expressed on certain types of these tumors $[19,20]$, we postulated that this molecule might represent a novel molecular target for immunotherapy against refractory T-cell lymphoma. Accordingly, we have developed a next-generation chimeric anti-CCR4 $\mathrm{mAb}, \mathrm{KM} 2760$, the Fc region of which is defucosylated [21], resulting in highly enhanced ADCC due to increased binding affinity to the $\mathrm{Fc} \gamma$ receptor $(\mathrm{Fc} \gamma \mathrm{R})$ on effector cells $[10,15]$. Importantly, based on our laboratory work on CCR4 [10, 14, 15, 19, 20, 22-25], and as an outcome of the success of this translational research, we have conducted a phase I clinical trial of defucosylated humanized antiCCR4 mAb in patients with CCR4-positive T-cell leukemia/lymphoma in Japan (clinical trials gov. identifier: NCT00355472). The KM2760 antibody can induce potent ADCC activity, whereas it does not mediate CDC, and has no anti-proliferative or direct apoptosis induction effect itself [22]. Accordingly, here we use KM2760 as a therapeutic $\mathrm{mAb}$ to evaluate ADCC in our humanized NOG mouse model. We selected two different types of CCR4expressing tumor cell lines as targets in our system. One, L428, is a Hodgkin lymphoma (HL) cell line, characterized by high production of TARC/CCL17, a ligand of CCR4 [23]. We have previously reported that KM2760 induced robust ADCC against L-428 by peripheral blood mononuclear cells (PBMC) from healthy individuals in vitro, and demonstrated a promising antitumor activity in the L-428bearing non-humanized SCID mouse model [14]. We also demonstrated that, in HL, specific ligands for CCR4 are produced by tumor cells, and then attract CCR4-expressing regulatory $\mathrm{T}$ (Treg) cells [10, 26-29] to the tumor, where they create a favorable environment for HL tumor cells to survive despite host immune recognition [23]. In addition,
KM2760 could deplete CCR4-positive T-cells and inhibit CD4-positiveCD25-positive T-cell migration induced by interaction between CCR4 and its ligands, in vitro [23]. Therefore, we here test KM2760-induced effects, using HL-bearing humanized NOG mice, against not only tumor cells but also HL tumor-infiltrating lymphocytes (TIL), in vivo. The other tumor cell line selected for study in this model is a cutaneous T-cell lymphoma (CTCL) cell line, $\mathrm{HH}$. We have also previously reported that KM2760 induced robust $\mathrm{ADCC}$ by healthy donor $\mathrm{PBMC}$ against $\mathrm{HH}$ in vitro, and a promising antitumor activity in the HH-bearing non-humanized SCID mouse model as well [30]. In the present study, we also tested KM2760-induced antitumor effects, using CTCL-bearing humanized NOG mice.

\section{Materials and methods}

\section{Cells}

PBMC were isolated from two healthy individuals using Ficoll-Paque (Pharmacia, Uppsala, Sweden) for use as effector cells in NOG mice. One was used for HL, the other for CTCL-bearing mice. These two donors provided informed written consent prior to sampling according to the Declaration of Helsinki, and the present study using human samples was approved by the institutional review board of Nagoya City University Graduate School of Medical Sciences.

Antibodies and flow cytometry

KM2760 has been described previously [15]. The following mAbs were used for flow cytometry: MultiTEST CD3 (clone SK7) FITC/CD16 (B73.1) + CD56 (NCAM 16.2) PE/CD45 (2D1) PerCP/CD19 (SJ25C1) APC Reagent, PEconjugated rat anti-mouse CD45 mAb (30-F11), Per-CP conjugated anti-human CD45 mAb (2D1), PE-conjugated anti-CD30 mAb (BerH8), and the appropriate isotype controls. All mAbs were purchased from BD Biosciences (San Jose, CA, USA). Whole blood cells from mice were treated with BD FACS ${ }^{\mathrm{TM}}$ Lysing Solution (BD Biosciences) for lysing red blood cells. Cells were analyzed by a FACScalibur (Becton Dickinson, San Jose, CA, USA) with the aid of FLOWJO software (Tree Star, Inc., Ashland, OR, USA).

Animals

Male NOG mice were purchased from the Central Institute for Experimental Animals (CIEA) (Kawasaki, Japan) and used at 6-8 weeks of age. All of the in vivo experiments were performed in conformity with the United Kingdom Co-ordinating Committee on Cancer Research (UKCCCR) 
Guidelines for the Welfare of Animals in Experimental Neoplasia (Second Edition).

\section{CCR4-expressing human cell lines}

The CCR4-expressing human HL cell line L-428 [23] and the CTCL cell line HH [30] were described previously.

HL mouse model

L-428 cells $\left(1.0 \times 10^{7}\right)$ suspended in $0.2 \mathrm{ml}$ RPMI-1640 medium with $50 \%$ matrigel (BD Matrigel ${ }^{\mathrm{TM}}$ Basement Membrane Matrix) were inoculated subcutaneously (s.c.) into 12 NOG mice. The tumor-bearing mice were divided into four groups of three mice each for treatment with (i) control (saline), (ii) human PBMC, (iii) KM2760, and (iv) human PBMC + KM2760, such that the mean tumor volumes were equal in each group. KM2760 (10 $\mu \mathrm{g} /$ mouse $)$ or control injections into the tail veins of the mice were started 28 days after tumor inoculation, when the mean tumor volume had reached $466( \pm 243, \mathrm{SD}) \mathrm{mm}^{3}$, and continued two times a week for 2 weeks. Human PBMC $\left(1 \times 10^{7}\right.$ cells/ mouse) or control intravenous (i.v.) injections into the mice were also started 28 days after tumor inoculation, and continued weekly for 2 weeks. Tumor volume was calculated by the following formula: tumor volume $\left(\mathrm{mm}^{3}\right)=0.5 \times$ (major diameter $) \times(\text { minor diameter })^{2}$.

\section{CTCL mouse model}

HH cells $\left(1.0 \times 10^{7}\right)$ suspended in $0.2 \mathrm{ml}$ RPMI-1640 medium with $50 \%$ matrigel were inoculated s.c. into 12 NOG mice. The tumor-bearing mice were divided into four groups of three mice each for treatment with (i) control (saline), (ii) human PBMC, (iii) KM2760, and (iv) human $\mathrm{PBMC}+\mathrm{KM} 2760$, 4 days after tumor inoculation, such that the mean serum LDH value was equal in each group. The concentration of LDH in serum was measured using LDH-J Reagent (KAINOS LABORATORIES, Inc. Tokyo, Japan) according to the manufacturer's instructions. KM2760 (30 $\mu \mathrm{g} / \mathrm{mouse}$ ) or control intraperitoneal (i.p.) injections into the mice were started 4 days after tumor inoculation, when the mean serum $\mathrm{LDH}$ value was $3,168 \pm 203 \mathrm{WU} / \mathrm{ml}$. Human PBMC $\left(1 \times 10^{7}\right.$ cells/mouse $)$ or control i.p. injections were also started 4 days after tumor inoculation and continued weekly for 2 weeks. Tumor volume was calculated by the following formula: tumor volume $\left(\mathrm{mm}^{3}\right)=0.5 \times($ major diameter $) \times(\text { minor diameter })^{2}$.

\section{Immunopathological analysis}

Hematoxylin and eosin (HE) staining and immunostaining using anti-FOXP3 mAb (236A/E7, Abcam plc, Cambridge,
UK), CD56 (1B6, Novocastra, Newcastle Upon Tyne, UK), and CD68 (KP1, DAKO Japan, Tokyo, Japan) were performed on formalin-fixed, paraffin-embedded sections as previously described $[19,20,23]$. The percent tumor necrosis in the L-428 study and the percent tumor lesion in the liver in the HH study was measured by two hematologists (A. Ito and T. Ishida) and a hematopathologist (H. Inagaki), and then averaged. Eight $400 \times$ high power fields (HPF) in the L-428 tumor area were randomly selected and CD56, CD68, and FOXP-positive cells were counted by two hematologists (A. Ito and T. Ishida) and a hematopathologist (H. Inagaki) and averaged.

\section{Soluble CD30 (sCD30) measurement}

The concentration of human sCD30 in mouse serum was measured by enzyme-linked immunosorbent assay (ELISA) using a human sCD30 ELISA (Bender MedSystems, Vienna, Austria) according to the manufacturer's instructions.

\section{Statistical analysis}

The differences in the tumor volume, $\%$ tumor necrosis, the number of tumor-infiltrating CD56, CD68, and FOXP3-positive cells/400 $\times$ HPF, \% CD16/56-positive and CD3-negative cells in mouse whole blood, human sCD30 concentration in mouse serum, and \% tumor lesion in the liver between two groups were examined with the Mann-Whitney $U$-test. Data were analyzed with the aid of StatView software (SAS Institute, version 5.0, Cary, NC, USA). In this study, $P<0.05$ was considered significant.

\section{Results}

KM2760 induces potent antitumor activity in the HL model of human PBMC-engrafted NOG mice

Injection of KM2760 together with human PBMC showed significant therapeutic efficacy as demonstrated by the effect on the tumor volume at day 16 after starting treatment (a mean of $649 \pm 267 \mathrm{~mm}^{3}, \mathrm{SD}$ ), compared to control $\left(1,693 \pm 632 \mathrm{~mm}^{3}, P=0.0495\right)$, human PBMC $(1,382 \pm$ $\left.378 \mathrm{~mm}^{3}, \quad P=0.0495\right)$, and KM2760 alone $(1,817 \pm$ $\left.825 \mathrm{~mm}^{3}, P=0.0495\right)$. Injection of KM2760 alone did not show any therapeutic efficacy as demonstrated by the lack of effect on tumor volume (Fig. 1a, b).

Injection of KM2760 together with human PBMC also showed significant therapeutic efficacy when assessed as the $\%$ tumor necrosis at day 16 after starting treatment $(59.9 \pm 8.9 \%)$, compared to control $(21.7 \pm 7.6 \%$, 
Fig. 1 KM2760 induces potent antitumor activity as demonstrated by its effect on tumor volume in the HL mouse model. a Antitumor activity of KM2760 against pre-established subcutaneous L-428 tumors. Tumor volume was calculated by the following formula: Tumor volume $\left(\mathrm{mm}^{3}\right)=0.5 \times($ major diameter $) \times(\text { minor diameter })^{2}$ Treatments were started when tumors were about $466 \mathrm{~mm}^{3}$ (28 days after L-428 inoculation). The tumor volume is presented as mean $\left(\mathrm{mm}^{3}\right)$. Black arrows indicate human PBMC or control injections, and arrowheads indicate KM2760 or control injections. Each group consists of three mice. Open circle, control (saline); open square, human PBMC; open triangle, KM2760; dark filled circle, KM2760 + human PBMC. Significant differences between the groups are indicated by asterisks, $P<0.05$ (n.s. not significant). b The photographs of each mouse were taken at day 16 after starting treatment. The L-428 tumors are demarcated by the thin dotted lines

\section{a}

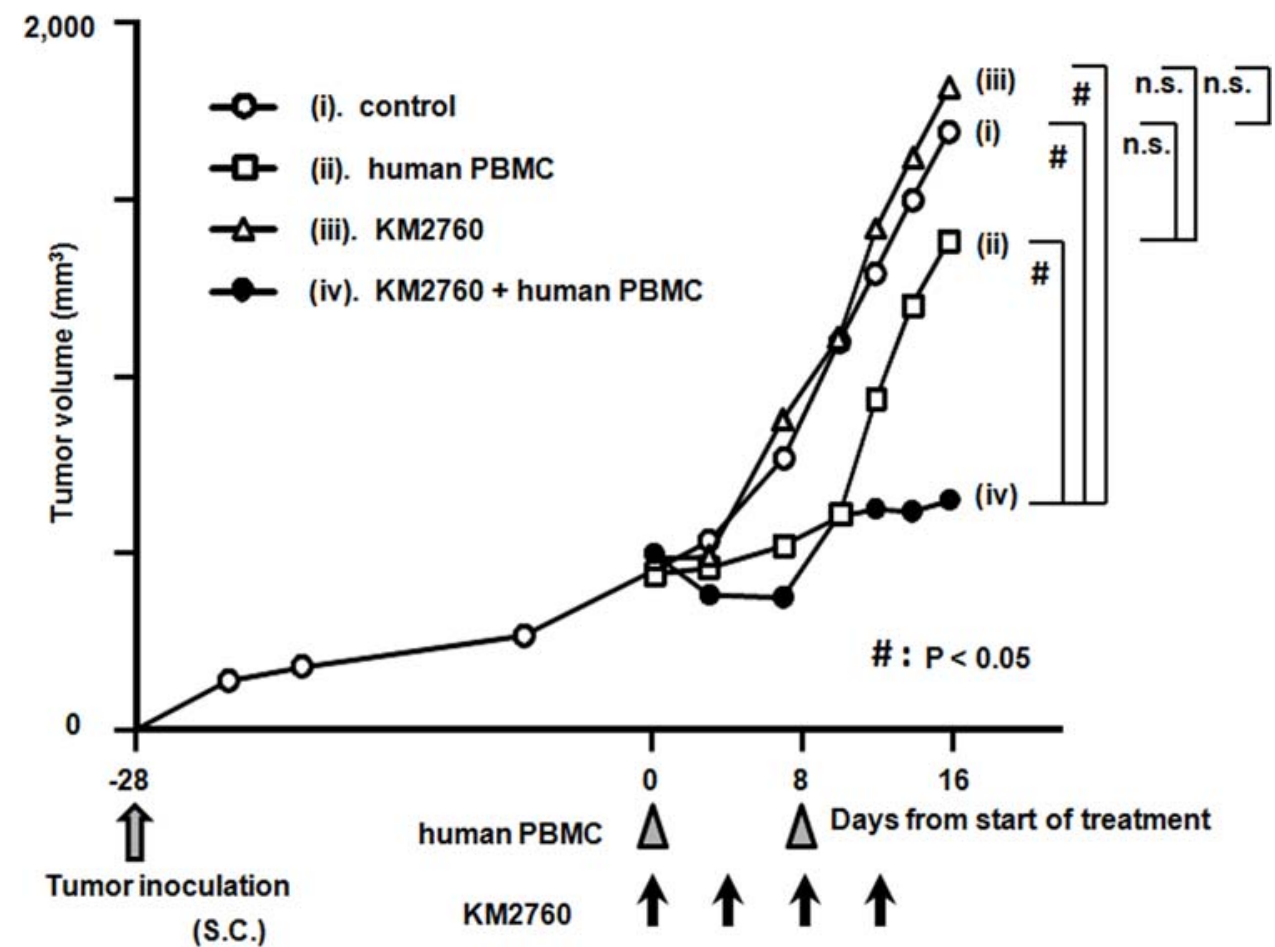

b Photographs at day 16

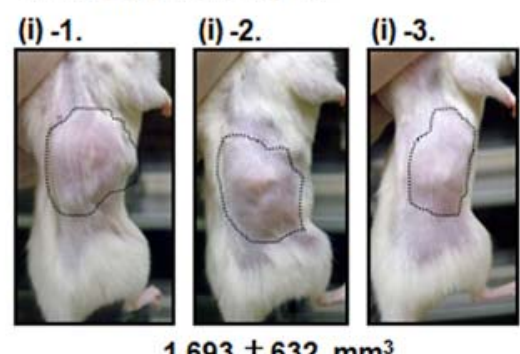

(ii) -1 .

(ii) $-\mathbf{2}$.

(ii) -3 .
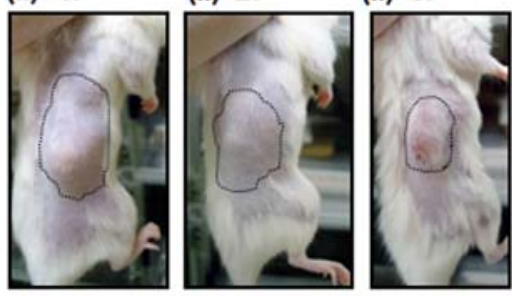

$1,382 \pm 378 \mathrm{~mm}^{3}$

(iii) -1

(iii) -3 .

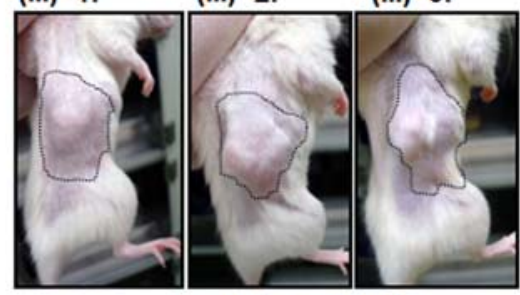

$1,817 \pm 825 \mathrm{~mm}^{3}$ (iv) -1 .

(iv) -2 .

(iv) -3 .

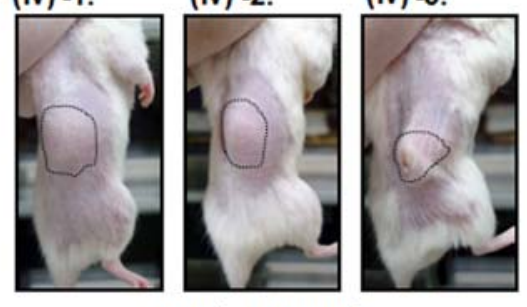

$649 \pm 267 \mathrm{~mm}^{3}$
$P=0.0495)$, human PBMC (48.6 $\pm 3.1 \%, P=0.0495)$, and KM2760 alone $(23.6 \pm 9.9 \%, P=0.0495)$. Injection of human PBMC alone also showed significant therapeutic efficacy, as demonstrated by the effect on the \% tumor necrosis, compared to control $(P=0.0495)$ or KM2760 alone $(P=0.0495)$. Injection of KM2760 alone did not have any therapeutic efficacy as reflected in the \% tumor necrosis (Fig. 2a, b). Representative images of tumor tissue from each mouse are shown in Fig. $2 b$.
KM2760 increases the number of intratumoral human CD56-positive NK cells

Injection of KM2760 together with human PBMC resulted in a significant increase in the number of L-428 tumor-infiltrating CD56-positive NK cells $(5.6 \pm 2.5 / 400 \times \mathrm{HPF})$, compared to PBMC alone $(0.9 \pm 0.1 / 400 \times \mathrm{HPF}, P=0.0495)$. Representative images of tumor tissue with CD56 immunostaining from each group are shown in Fig. 3a. 
Fig. 2 KM2760 induces potent antitumor activity as demonstrated by its effect on the \% tumor necrosis in the HL mouse model. a The percent L-428 tumor necrosis of each mouse at day 16 from the start of treatment is plotted. Significant differences between the groups are indicated by asterisks, $P<0.05$ (n.s. not significant). b Each tumor tissue stained with HE is shown (scale bar, $500 \mu \mathrm{m})$. In general, tumor tissues from the KM2760 + human PBMC group (group iv) show extensive necrosis a

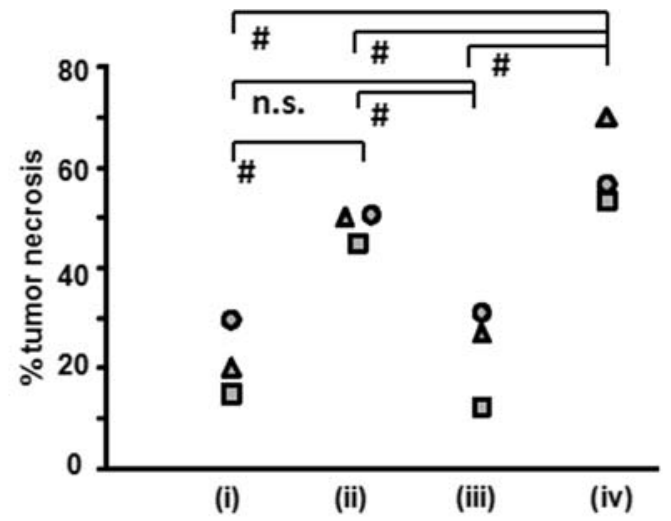

b (i) -1

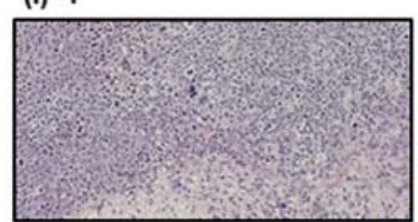

(i) -2

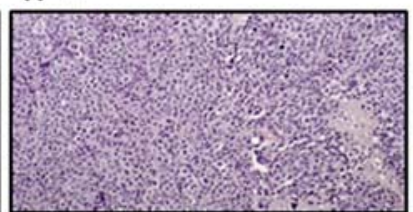

(i) -3 (ii) -1

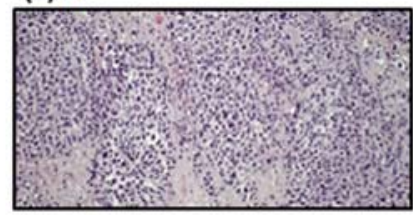

(iii) -1

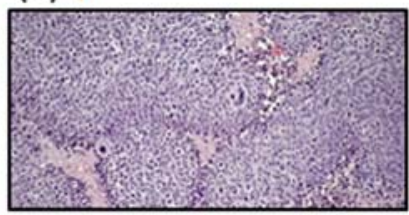

(iv) -1

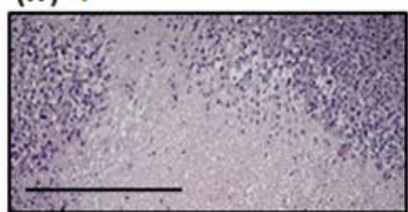

(ii) -2

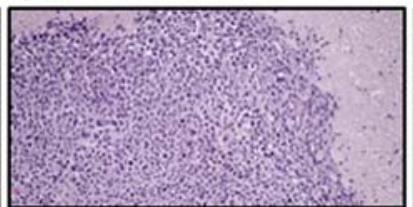

(iii) -2

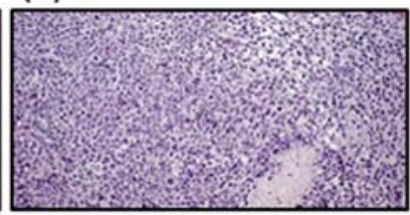

(iv) -2

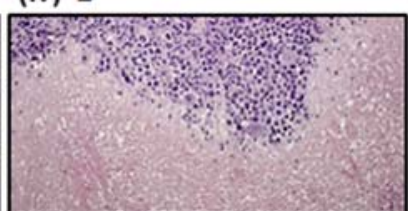

$\#: P<0.05$

(i). control

(ii). human PBMC

(iii). KM2760

(iv). KM2760 + human PBMC

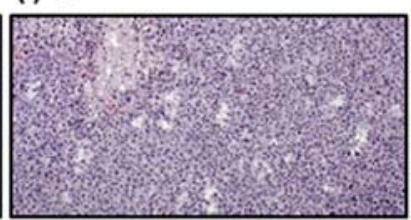

(ii) -3

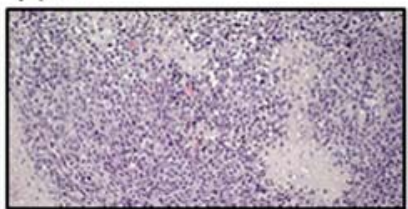

(iii) -3

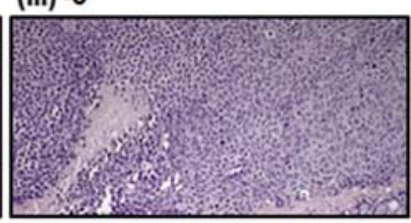

(iv) -3

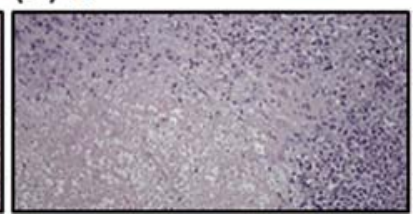

KM2760 has no influence on the number of intratumoral human CD68-positive monocytes/macrophages

The number of L-428 tumor-infiltrating CD68-positive monocytes/macrophages in NOG mice injected with KM2760 together with human PBMC was $0.73 \pm 0.34$ / $400 \times \mathrm{HPF}$, compared to $0.58 \pm 0.16 / 400 \times \mathrm{HPF}$ with human PBMC alone. This difference was not significant.

KM2760 reduces the number of intratumoral human FOXP3-positive Treg cells

Injection of KM2760 together with human PBMC resulted in a significant decrease of the number of L-428 tumor- infiltrating FOXP3-positive Treg cells (4.3 $\pm 0.6 /$ $400 \times \mathrm{HPF})$, compared to PBMC alone $(13.8 \pm 8.7 /$ $400 \times \mathrm{HPF}, P=0.0495)$. Representative images of tumor tissue with FOXP3 immunostaining from each group are shown in Fig. $3 b$.

KM2760 increases the percentage of NK cells among human CD45-positive cells in HL mouse whole blood

Injection of KM2760 together with human PBMC resulted in a significant increase in the proportion of CD16/56-positive NK cells among the human CD45-positive cells in HL mouse whole blood $(5.7 \pm 2.4 \%)$, compared to PBMC alone $(1.8 \pm 0.1 \%, P=0.0463)$ (Fig. 3c). 
a

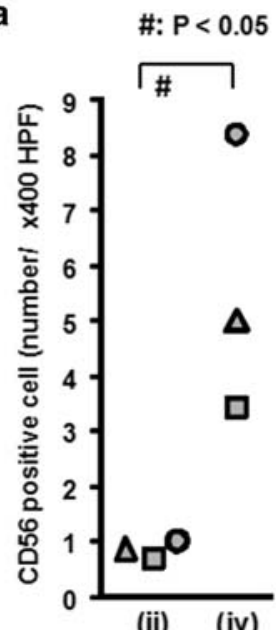

(ii) $-1 \quad$ CD56

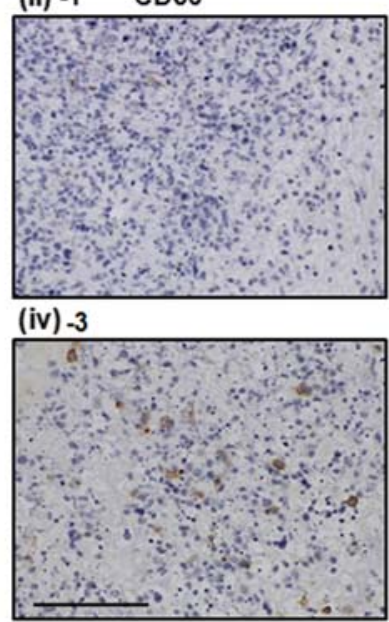

b

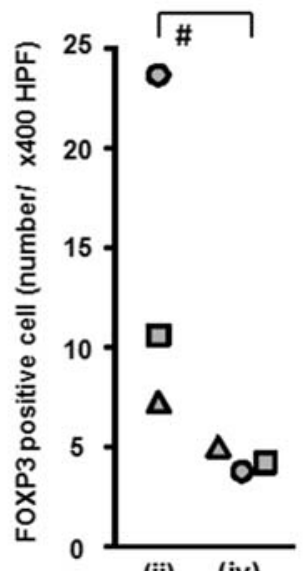

(ii) $-1 \quad$ FOXP3

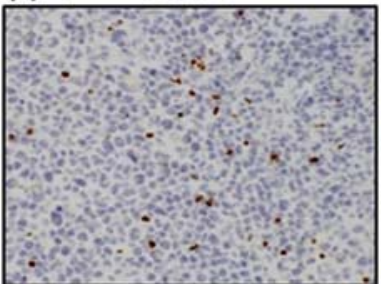

(iv) -3

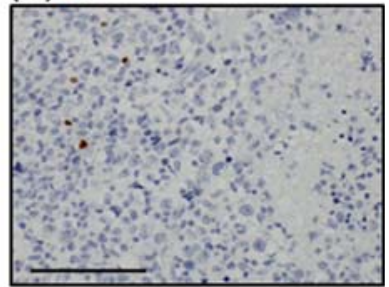

C

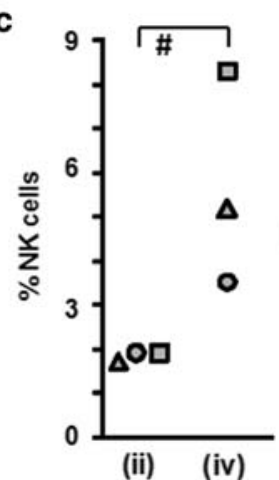

(ii) -1

(ii) -2

(ii) -3

(ii) (iv)
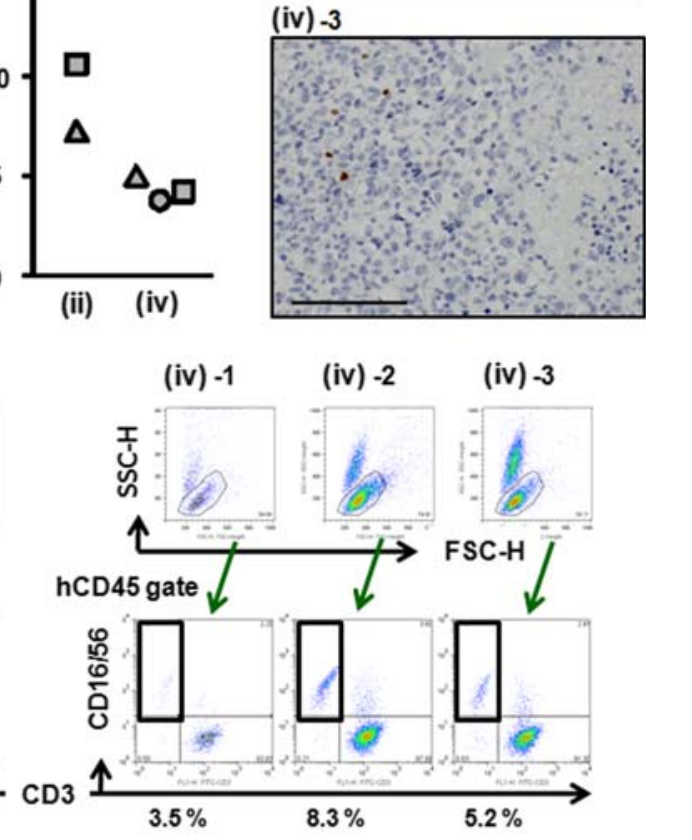

(ii). human PBMC (iv). KM2760 + human PBMC

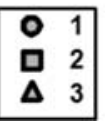

Fig. 3 Effect of KM2760 treatment on the characteristics of TIL and the increased \% NK cells in whole blood in the HL mouse model. a The numbers of CD56-positive cells in the $\times 400$ HPF of each mouse are plotted. Representative images stained with CD56 for each group [injection of human PBMC (group ii) alone or KM2760 + human PBMC (group iv)] are shown (scale bar, $100 \mu \mathrm{m}$ ). KM2760 significantly increased the number of tumor-infiltrating CD56-positive NK cells. b The number of FOXP3-positive cells in the $\times 400 \mathrm{HPF}$ of each mouse are plotted. Representative images stained with FOXP3 in

KM2760 induces potent antitumor activity in the CTCL model of human PBMC-engrafted NOG mice

Injection of KM2760 together with human PBMC showed significant therapeutic efficacy as demonstrated by the effect on tumor volume at day 15 after starting treatment $\left(25 \pm 36 \mathrm{~mm}^{3}\right)$, compared to control $\left(1,627 \pm 1,401 \mathrm{~mm}^{3}\right.$, $P=0.0495)$, human PBMC $\left(547 \pm 176 \mathrm{~mm}^{3}, P=0.0495\right)$ or KM2760 alone $\left(2,914 \pm 1,401 \mathrm{~mm}^{3}, P=0.0495\right)$. Injection of human PBMC alone also showed significant therapeutic efficacy as demonstrated by the effect on tumor volume at day 15 , compared to control $(P=0.0495)$ or KM2760 alone $(P=0.0495)$. KM2760 alone did not show any therapeutic efficacy on tumor volume (Fig. 4a, b). each group [injection of human PBMC (group ii) alone or KM2760 + human PBMC (group iv)] are shown (scale bar, $100 \mu \mathrm{m}$ ). KM2760 significantly decreased the number of tumor-infiltrating FOXP3-positive Treg cells. $\mathbf{c}$ The percentage of CD56-positive cells among human CD45-positive cells in whole blood of each HL mouse is plotted. Flow cytometry analyses of each mouse are shown. KM2760 significantly increased the percentage of human CD56-positive cells in mouse whole blood

Injection of KM2760 together with human PBMC also showed significant therapeutic efficacy in terms of the percent of tumor lesions in the liver at day $15(0.6 \pm 0.4 \%)$, compared to control $(59.3 \pm 44.7 \%, P=0.0495)$, human PBMC $(15.0 \pm 5.0 \%, P=0.0495)$, and KM2760 alone $(47.0 \pm 43.0 \%, P=0.0495)$. KM2760 alone did not show any therapeutic efficacy as demonstrated by the effect on the $\%$ tumor lesion in the liver (Fig. 5a). Representative images of tumor-affected liver from each mouse are shown in Fig. 5b, c.

$\mathrm{HH}$ was confirmed to be positive for CD30 by flow cytometry (Fig. 6a). Because it has been reported that serum levels of sCD30 correlate with the tumor burden in patients with CD30-expressing tumors [31-33], we 
Fig. 4 KM2760 induces potent antitumor activity as demonstrated by its effect on tumor volume in the CTCL model of human PBMC-engrafted NOG mice. a Antitumor activity of KM2760 against subcutaneous HH tumors. Tumor volume was calculated by the following formula: Tumor volume $\left(\mathrm{mm}^{3}\right)=0.5 \times($ major diameter $) \times(\text { minor diameter })^{2}$. Treatments were started 4 days after $\mathrm{HH}$ inoculation. The tumor volume is presented as mean $\left(\mathrm{mm}^{3}\right)$. Black arrows indicate human PBMC or control injections, and arrowheads indicate KM2760 or control injections. Each group consists of three mice. Open circle, control (saline); open square, human PBMC; open triangle, KM2760; dark filled circle, KM2760 + human PBMC.

Significant differences between the groups are indicated by asterisks, $P<0.05$ (n.s. not significant). b The photographs of each mouse were taken at day 15 from the start of treatment. The HH tumors are demarcated by thin dotted lines

\section{a}

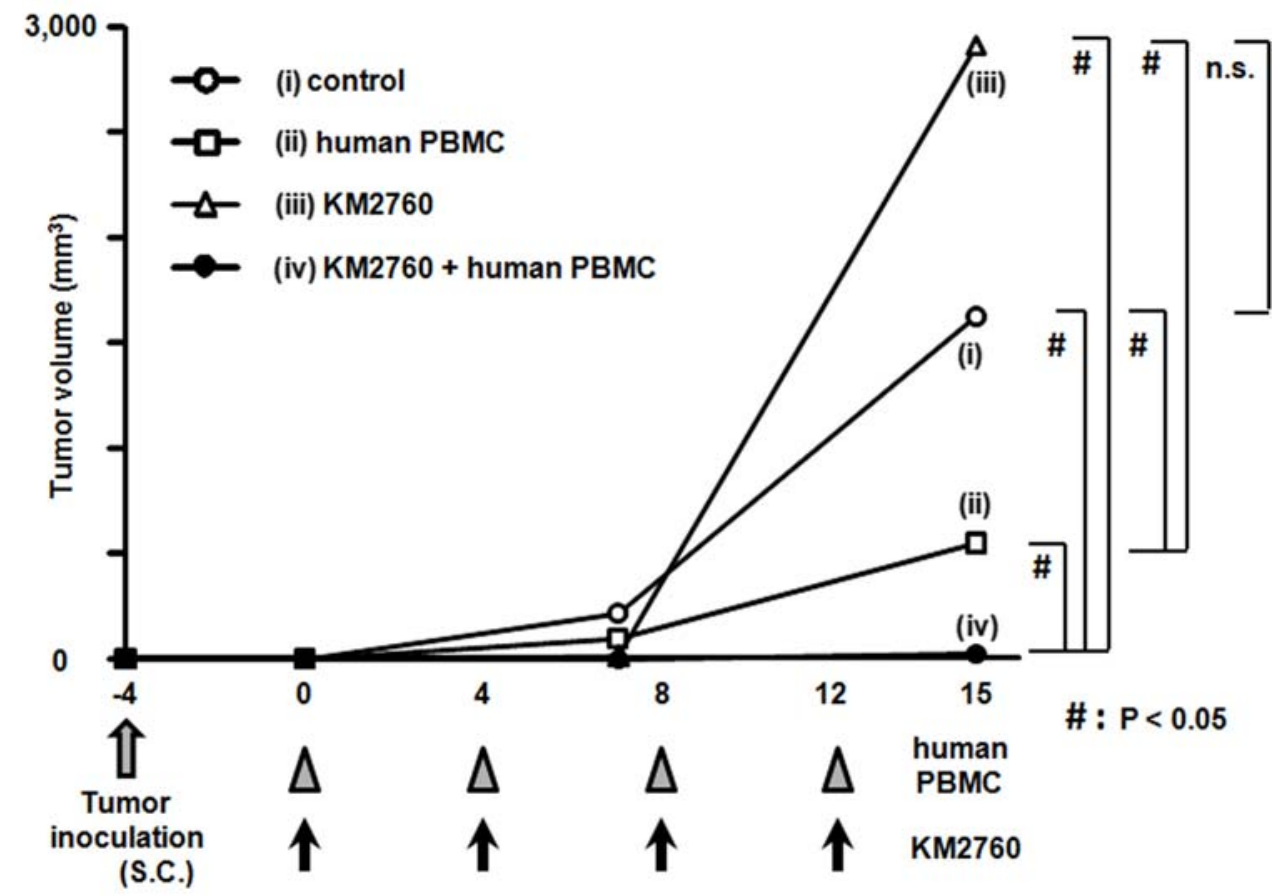

b

\section{Photographs at day 15}

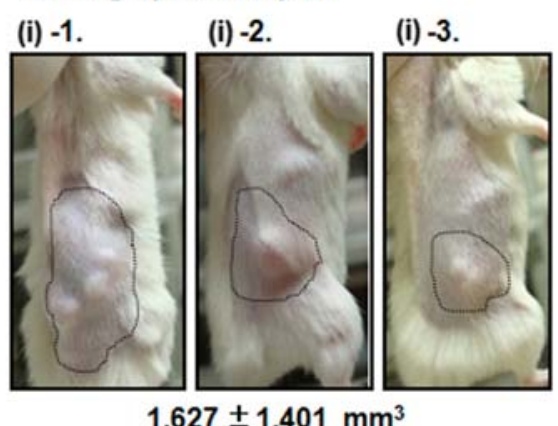

(ii) -1 .

(ii) -2 .

(ii) -3 .

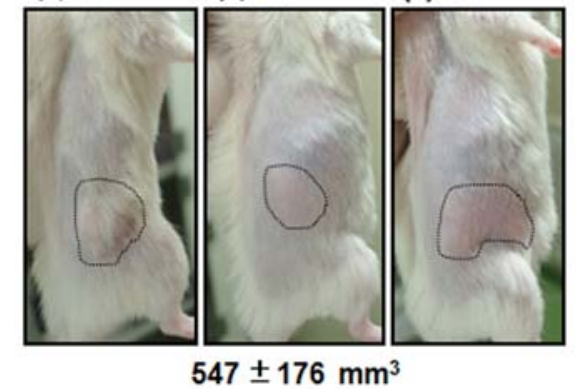

(iii) -1 .

(iii) -2 .

(iii) -3 .

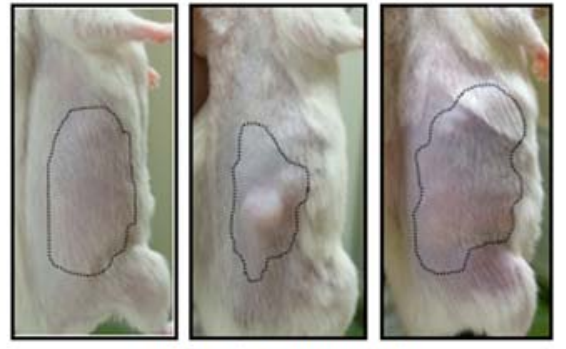

$2,914 \pm 1,401 \mathrm{~mm}^{3}$ (iv) -1 .

(iv) -2 .

iv) -3 .

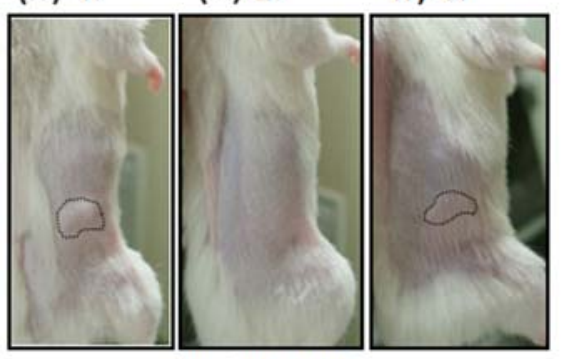

$25 \pm 36 \mathrm{~mm}^{3}$ measured human sCD30 concentrations in mouse serum as a surrogate marker reflecting therapeutic efficacy. The serum sCD30 concentrations of KM2760 and human PBMC recipient NOG mice at day 15 after starting treatment $(2,142 \pm 810 \mathrm{U} / \mathrm{ml})$ were significantly lower than in control mice $(53,418 \pm 28,646 \mathrm{U} / \mathrm{ml}, P=0.0495)$, human PBMC recipient mice $(5,926 \pm 3,034 \mathrm{U} / \mathrm{ml}, P=0.0495)$, and KM2760 recipient mice $(44,027 \pm 29,830 \mathrm{U} / \mathrm{ml}$, $P=0.0495)$. The serum sCD30 concentrations of human PBMC recipient NOG mice were also significantly lower than controls $(P=0.0495)$, and KM2760 recipient mice $(P=0.0495)$. Injection of KM2760 alone did not show any therapeutic efficacy as demonstrated by the sCD30 concentration. 
Fig. 5 KM2760 induces potent antitumor activity as demonstrated by its effect on the \% liver tumor lesions in the $\mathrm{HH}$ model of human PBMC-engrafted NOG mice. a The percent tumor necrosis of each mouse at day 16 after the start of treatment is plotted. Significant differences between the groups are indicated by asterisks, $P<0.05$ (n.s. not significant). b The photographs of a mouse of control (group i), and a mouse from the KM2760 + human PBMC (group iv), were taken at day 15 after the start of treatment.

Almost the entire liver of the control mouse (group i)-3 was diffusely infiltrated by $\mathrm{HH}$ cells and enlarged. c Each liver tissue stained with HE is shown (scale bar, $500 \mu \mathrm{m})$ a

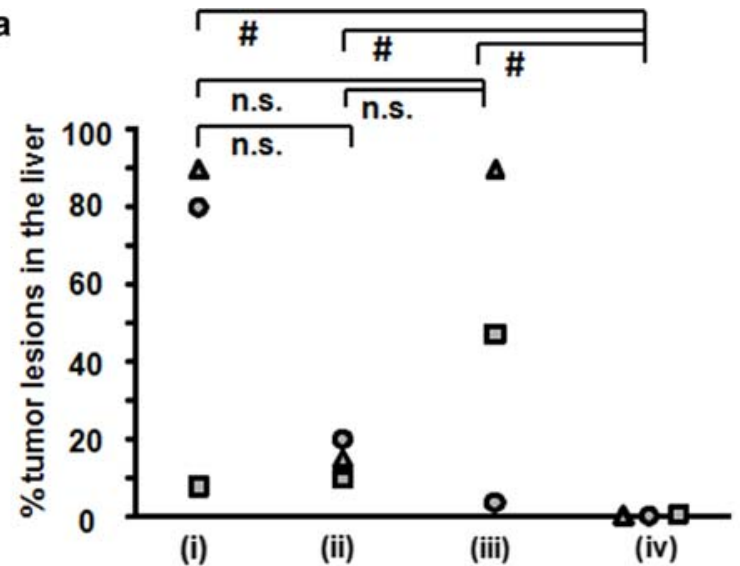

b

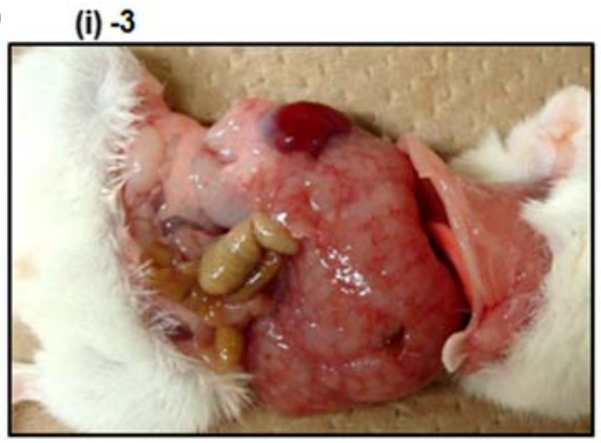

C (i) -1

(i) -2

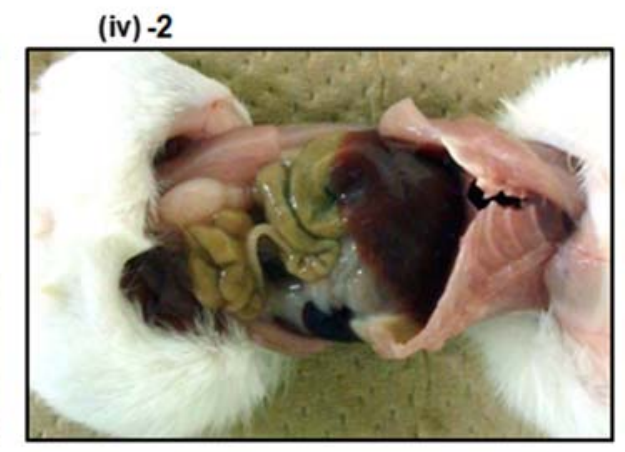

(i). control

(ii). human PBMC

(iii). KM2760

(iv). KM2760 + human PBMC

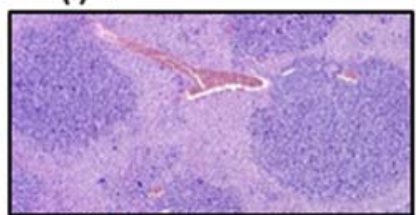

(ii) -1

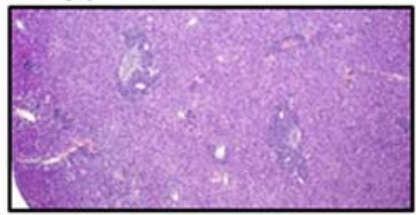

(iii) -1

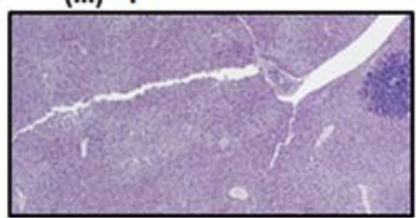

(iv) -1

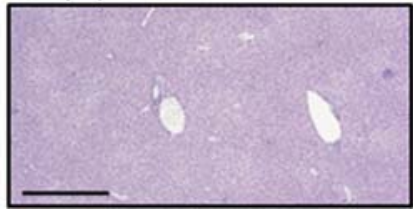

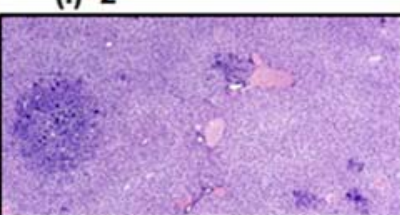

(ii) -2

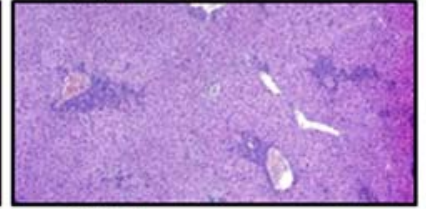

(iii) -2

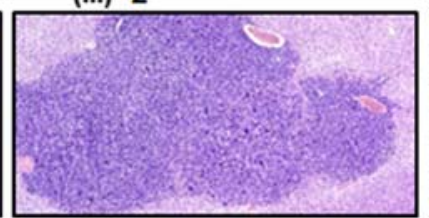

(iv) -2

(iv) -3

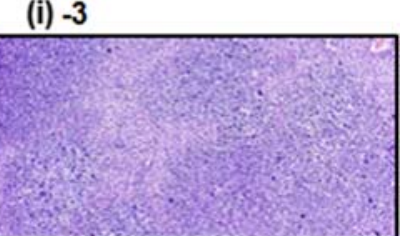

(ii) -3

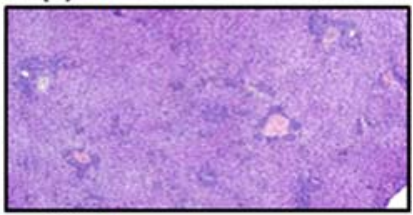

(iii) -3
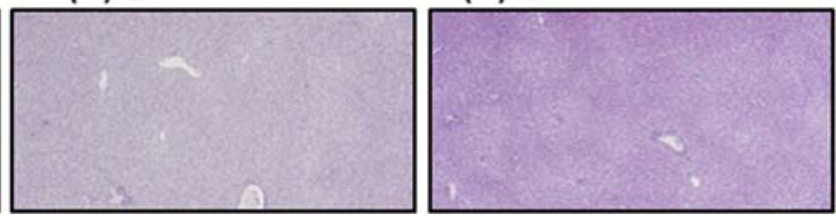
Fig. 6 KM2760 reduces serum sCD30 concentration, and increases the \% NK cells in whole blood in the CTCL mouse model. a HH was stained with PE-conjugated anti-CD30 mAb (blank histogram) or isotype control mAb (filled histogram). b The serum SCD30 concentrations of each CTCL mouse are plotted. KM2760 and human PBMC recipient NOG mice had significantly lower levels of sCD30 than control, human PBMC recipient, and KM2760 recipient mice. Injection of KM2760 alone did not show any therapeutic efficacy as reflected in serum $\mathrm{SCD} 30$ concentration. c The percentage of CD56positive cells among human CD45-positive cells in whole blood of each CTCL mouse is plotted. Flow cytometry analyses of each mouse are shown. KM2760 significantly increased the percentage of human CD56-positive cells in these mice a

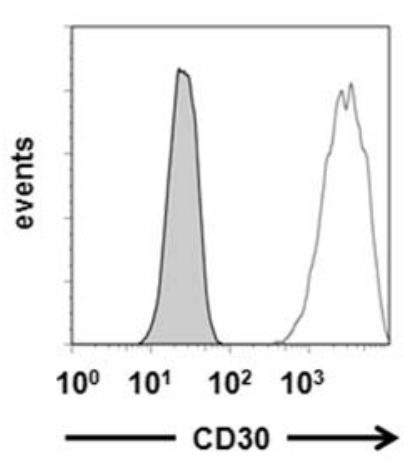

c

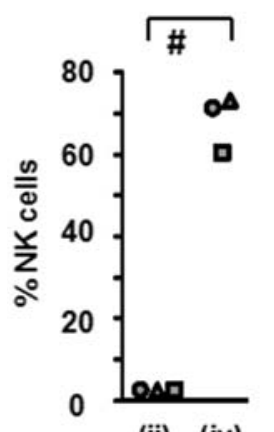

(ii) -1

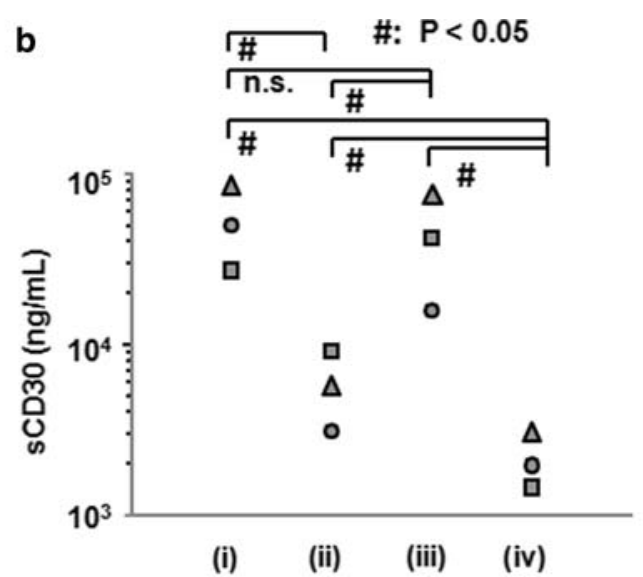

(i) (ii) (iii) (iv)

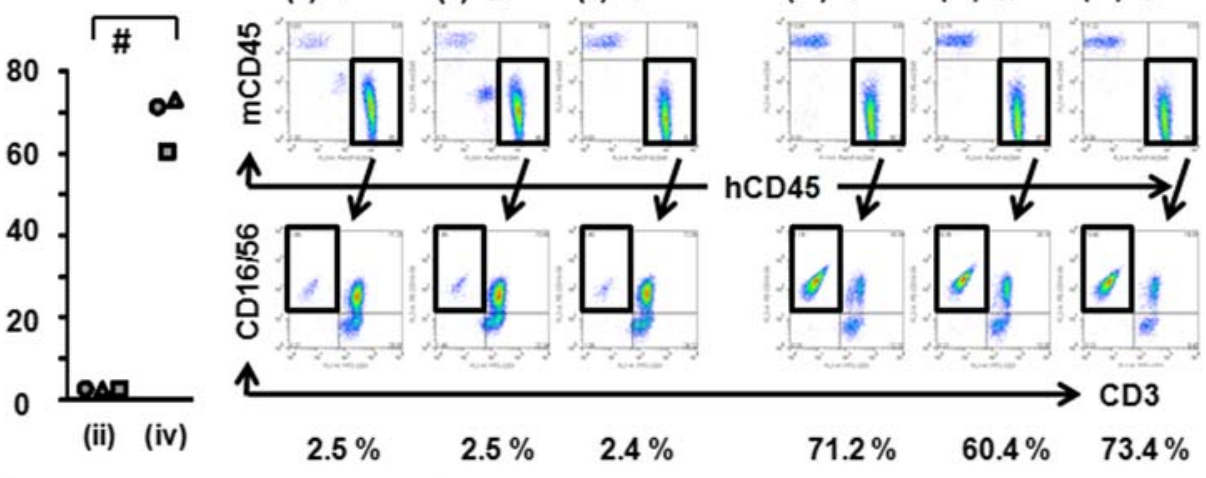

\begin{tabular}{|c|c|}
\hline $\begin{array}{l}\text { (i). control } \\
\text { (ii). human PBMC } \\
\text { (iii). KM2760 } \\
\text { (iv). KM2760 + human PBMC }\end{array}$ & $\begin{array}{ll}\mathbf{0} & 1 \\
\mathbf{D} & 2 \\
\mathbf{\Delta} & 3\end{array}$ \\
\hline
\end{tabular}

(ii) -3

(iv) -1 (iv) -3
KM2760 increases the percentage of NK cells among human CD45-positive cells in CTCL mouse whole blood

Injection of KM2760 together with human PBMC resulted in a significant increase of the proportion of CD16/56-positive NK cells among human CD45-positive cells in HL mouse whole blood $(68.3 \pm 7.0 \%)$, compared to PBMC alone $(2.5 \pm 0.1 \%, P=0.0463)$ (Fig. 6c).

\section{Discussion}

The present study showed that the combined injection of KM2760 together with human PBMC exhibited significant therapeutic efficacy, but that KM2760 alone failed to do so in either the HL or CTCL model. This finding indicates that the KM2760-induced antitumor effects observed here are completely dependent on the engrafted human PBMC, and is consistent with the fact that KM2760 can induce only ADCC activity, but does not mediate CDC or direct antitumor activities [22]. This finding also confirms that the endogenous immune cells in NOG mice cannot mediate the antitumor action of the therapeutic mAb. This is a very important issue for the evaluation of human ADCC in vivo. Snanoudj et al., observed ADCC mediated by engrafted human NK cells in NOD/SCID mice in vivo [34]. However, in this system, the effect of the mAb mediated by endogenous murine immune cells could not be completely excluded. Indeed, other investigators have demonstrated that endogenous immune cells in mice can mediate significant antitumor activities of the therapeutic $\mathrm{mAb}$ in the tumor-bearing NOD/SCID mouse model [35-37], and furthermore, we ourselves confirmed almost the same finding using KM2760 as the therapeutic mAb (unpublished data). On the other hand, the injection of human PBMC alone exhibited significant therapeutic efficacy, as demonstrated by the effect on the \% tumor necrosis in the HL model, and the effect on both tumor volume and serum sCD30 levels in the CTCL model compared to controls or KM2760 alone. This antitumor effect seems to be mainly due to NK cells in the engrafted human PBMC, which play an important part in the first line of defense against tumors [38]. 
We found here that KM2760 treatment resulted in an increased number of intratumoral human CD56-positive NK cells. NK cells should be efficiently delivered to CCR4expressing tumor sites by KM2760 via interaction with $\mathrm{Fc} \gamma \mathrm{R}$, and there mediate KM2760-induced ADCC against the tumor cells. This immunopathological finding provided the first evidence that NK cells actually do function as effectors of human ADCC in vivo, and is consistent with the in vitro findings of the critical importance of NK cells as human ADCC effector cells [39]. On the other hand, in our system, a role for CD68-positive monocytes/macrophages as effector cells mediating the antitumor action of the therapeutic mAb could not be demonstrated.

We must emphasize the present finding that KM2760 reduced the number of intratumoral human FOXP3positive Treg cells. This is important because much recent evidence has demonstrated that the presence of Treg cells in TIL is one of the most crucial tumor immune-evasion mechanisms and the main obstacle to successful tumor immunotherapy [10, 40-42]. Our previous observation of KM2760-induced Treg reduction in vitro $[22,23]$ was confirmed by the present study of humanized mice in vivo. The recognition of the importance of Treg cells in different cancers will allow the rational design of more effective treatments. Depletion of Treg cells in patients with tumors could become a promising strategy for boosting tumorassociated antigen-specific immunity. For instance, the administration of fully human anti-CTLA-4 blocking mAb to advanced cancer patients increases immune-mediated tumor destruction in some subjects [43-45]. The present observation in the humanized mouse model in vivo further reassures us that anti-CCR4 $\mathrm{mAb}$ could be an ideal treatment modality for patients with CCR4-positive neoplasms, and could also be used for treatment of many other types of cancer by overcoming the suppressive effect of Treg cells on the host's immune response to tumor cells.

The injection of KM2760 together with human PBMC resulted in a significant increase in the percentage of NK cells among human CD45-positive cells in the animals' blood and was observed in both HL and CTCL models. This suggests that stimulation via $\mathrm{Fc} \gamma \mathrm{R}$ results in peripheral blood-derived human NK cell expansion in mice. This might agree with the two reports that (1) NK cell activation could be induced by $\mathrm{Fc} \gamma \mathrm{R}$ stimulation alone, by Bryceson et al. [46], and (2) defucosylated mAb efficiently activated NK cells via antigen-specific $\mathrm{F} c \gamma \mathrm{R}$ signals during ADCC, by ourselves [24].

In conclusion, a novel tumor-bearing humanized animal model created using NOG mice, by which human ADCC can be evaluated, has been established. This model can overcome the limitations to preclinical in vivo investigations of ADCC caused by species incompatibility between humans and mice. With this model, we can perform appro- priate preclinical evaluations of novel therapeutic $\mathrm{mAb}$, and of combination treatment strategies with the many types of therapeutic mAbs, such as rituximab, trastuzumab, and cetuximab, and other antitumor agents. Using this system, the present study demonstrated that KM2760 showed potent antitumor activity mediated by robust ADCC, and therefore could be an ideal treatment modality for patients with CCR4-positive lymphoma. In addition, KM2760 reduced the number of tumor-infiltrating FOXP3-positive Treg cells in vivo, and therefore could also be used as a novel strategy for treatment of many other types of cancer to overcome the suppressive effect of Treg cells on the host's immune response to tumor cells. In the near future, the efficacy of the defucosylated anti-CCR $4 \mathrm{mAb}$ will be established in clinical trials in humans.

Acknowledgments We thank Kyowa Hakko Kogyo Corp. for providing us with chimeric anti-CCR4 mAb (KM2760), and Ms Chiori Fukuyama for her excellent technical assistance. Grants-in-Aid for General Scientific Research (No. 19390266, R. Ueda, No. 80405183, T. Ishida), and for Scientific Research on Priority Areas (No. 17016065 \& 16062101, R. Ueda) from the Ministry of Education, Culture, Science, Sports, and Technology, Japan; Grants-in-Aid for Cancer Research from the Ministry of Health, Labor, and Welfare, Japan (No. 17S-1, \& 17-16, S. Iida, No. 19-8, T. Ishida).

Open Access This article is distributed under the terms of the Creative Commons Attribution Noncommercial License which permits any noncommercial use, distribution, and reproduction in any medium, provided the original author(s) and source are credited.

\section{References}

1. Coiffier B, Lepage E, Briere J, Herbrecht R, Tilly H, Bouabdallah R, Morel P, Van Den Neste E, Salles G, Gaulard P, Reyes F, Lederlin P, Gisselbrecht C (2002) CHOP chemotherapy plus rituximab compared with $\mathrm{CHOP}$ alone in elderly patients with diffuse large-B-cell lymphoma. N Engl J Med 346:235-242

2. Pfreundschuh M, Trümper L, Osterborg A, Pettengell R, Trneny M, Imrie K, Ma D, Gill D, Walewski J, Zinzani PL, Stahel R, Kvaloy S, Shpilberg O, Jaeger U, Hansen M, Lehtinen T, LópezGuillermo A, Corrado C, Scheliga A, Milpied N, Mendila M, Rashford M, Kuhnt E, Loeffler M, Group MabTheraInternationalTrial (2006) CHOP-like chemotherapy plus rituximab versus CHOP-like chemotherapy alone in young patients with goodprognosis diffuse large-B-cell lymphoma: a randomised controlled trial by the MabThera International Trial (MInT) Group. Lancet Oncol 7:379-391

3. Slamon DJ, Leyland-Jones B, Shak S, Fuchs H, Paton V, Bajamonde A, Fleming T, Eiermann W, Wolter J, Pegram M, Baselga J, Norton L (2001) Use of chemotherapy plus a monoclonal antibody against HER2 for metastatic breast cancer that overexpresses HER2. N Engl J Med 344:783-792

4. Hurwitz H, Fehrenbacher L, Novotny W, Cartwright T, Hainsworth J, Heim W, Berlin J, Baron A, Griffing S, Holmgren E, Ferrara N, Fyfe G, Rogers B, Ross R, Kabbinavar F (2004) Bevacizumab plus irinotecan, fluorouracil, and leucovorin for metastatic colorectal cancer. N Engl J Med 350:2335-2342

5. Sandler A, Gray R, Perry MC, Brahmer J, Schiller JH, Dowlati A, Lilenbaum R, Johnson DH (2006) Paclitaxel-carboplatin alone or 
with bevacizumab for non-small-cell lung cancer. N Engl J Med 355:2542-2550

6. Bonner JA, Harari PM, Giralt J, Azarnia N, Shin DM, Cohen RB, Jones CU, Sur R, Raben D, Jassem J, Ove R, Kies MS, Baselga J, Youssoufian H, Amellal N, Rowinsky EK, Ang KK (2006) Radiotherapy plus cetuximab for squamous-cell carcinoma of the head and neck. N Engl J Med 354:567-578

7. Smith MR (2003) Rituximab (monoclonal anti-CD20 antibody): mechanisms of action and resistance. Oncogene 22:7359-7368

8. Carter P (2001) Improving the efficacy of antibody-based cancer therapies. Nat Rev Cancer 1:118-129

9. Glennie MJ, van de Winkel JG (2003) Renaissance of cancer therapeutic antibodies. Drug Discov Today 8:503-510

10. Ishida T, Ueda R (2006) CCR4 as a novel molecular target for immunotherapy of cancer. Cancer Sci 97:1139-1146

11. Voso MT, Pantel G, Rutella S, Weis M, D’Alò F, Urbano R, Leone G, Haas R, Hohaus S (2002) Rituximab reduces the number of peripheral blood B-cells in vitro mainly by effector cell-mediated mechanisms. Haematologica 87:918-925

12. Clynes RA, TowersTL PrestaLG, Ravetch JV (2000) Inhibitory Fc receptors modulate in vivo cytoxicity against tumor targets. Nat Med 6:443-446

13. Cartron G, Dacheux L, Salles G, Solal-Celigny P, Bardos P, Colombat P, Watier H (2002) Therapeutic activity of humanized anti-CD20 monoclonal antibody and polymorphism in IgG Fc receptor FcgRIIIa gene. Blood 99:754-758

14. Ishida $T$, Ishii $T$, Inagaki $A$, Yano $H$, Kusumoto $S$, Ri M, Komatsu H, Iida S, Inagaki H, Ueda R (2006) The CCR4 as a novel-specific molecular target for immunotherapy in Hodgkin lymphoma. Leukemia 20:2162-2168

15. Niwa R, Shoji-Hosaka E, Sakurada M, Shinkawa T, Uchida K, Nakamura K, Matsushima K, Ueda R, Hanai N, Shitara K (2004) Defucosylated chimeric anti-CC chemokine receptor 4 IgG1 with enhanced antibody-dependent cellular cytotoxicity shows potent therapeutic activity to T-cell leukemia and lymphoma. Cancer Res 64:2127-2133

16. Ito M, Hiramatsu H, Kobayashi K, Suzue K, Kawahata M, Hioki K, Ueyama Y, Koyanagi Y, Sugamura K, Tsuji K, Heike T, Nakahata T (2002) NOD/SCID/gamma(c)(null) mouse: an excellent recipient mouse model for engraftment of human cells. Blood 100:3175-3182

17. Ito M, Kobayashi K, Nakahata T (2008) NOD/Shi-scid IL2r $\gamma^{\text {null }}$ (NOG) mice more appropriate for humanized mouse models. Curr Top Microbiol Immunol 324:53-76

18. Armitage J, Vose J, Weisenburger D (2008) International peripheral T-cell and natural killer/T-cell lymphoma study: pathology findings and clinical outcomes. J Clin Oncol 26:4124-4130

19. Ishida $\mathrm{T}$, Utsunomiya $\mathrm{A}$, Iida $\mathrm{S}$, Inagaki $\mathrm{H}$, Takatsuka $\mathrm{Y}$, Kusumoto S, Takeuchi G, Shimizu S, Ito M, Komatsu H, Wakita A, Eimoto T, Matsushima K, Ueda R (2003) Clinical significance of CCR4 expression in adult T-cell leukemia/lymphoma (ATLL): its close association with skin involvement and unfavorable outcome. Clin Cancer Res 9:3625-3634

20. Ishida $T$, Inagaki H, Utsunomiya A, Takatsuka Y, Komatsu H, Iida S, Takeuchi G, Eimoto T, Nakamura S, Ueda R (2004) CXC chemokine receptor 3 and $\mathrm{CC}$ chemokine receptor 4 expression in T-cell and NK-cell lymphomas with special reference to clinicopathological significance for peripheral T-cell lymphoma, unspecified. Clin Cancer Res 10:5494-5500

21. Shinkawa T, Nakamura K, Yamane N, Shoji-Hosaka E, Kanda Y, Sakurada M, Uchida K, Anazawa H, Satoh M, Yamasaki M, Hanai N, Shitara K (2003) The absence of fucose but not the presence of galactose or bisecting $\mathrm{N}$-acetylglucosamine of human IgG1 complex-type oligosaccharides shows the critical role of enhancing antibody-dependent cellular cytotoxicity. J Biol Chem 278:3466-3473
22. Ishida T, Iida S, Akatsuka Y, Ishii T, Miyazaki M, Komatsu H, Inagaki H, Okada N, Fujita T, Shitara K, Akinaga S, Takahashi T, Utsunomiya A, Ueda R (2004) The CC chemokine receptor 4 as a novel-specific molecular target for immunotherapy in adult T-cell leukemia/lymphoma. Clin Cancer Res 10:7529-7539

23. Ishida $T$, Ishii $T$, Inagaki $A$, Yano $H$, Komatsu $H$, Iida $S$, Inagaki H, Ueda R (2006) Specific recruitment of CCR4-positive regulatory $\mathrm{T}$ cells in Hodgkin lymphoma fosters immune privilege. Cancer Res 66:5716-5722

24. Niwa R, Sakurada M, Kobayashi Y, Uehara A, Matsushima K, Ueda R, Nakamura K, Shitara K (2005) Enhanced natural killer cell binding and activation by low-fucose IgG1 antibody results in potent antibody-dependent cellular cytotoxicity induction at lower antigen density. Clin Cancer Res 11:2327-2336

25. Yano $H$, Ishida $T$, Imada $K$, Sakai $T$, Ishii $T$, Inagaki $A$, Iida $S$, Uchiyama T, Ueda R (2008) Augmentation of antitumour activity of defucosylated chimeric anti-CCR4 monoclonal antibody in SCID mouse model of adult T-cell leukaemia/lymphoma using G-CSF. Br J Haematol 140:586-589

26. Iellem A, Mariani M, Lang R, Recalde $H$, Panina-Bordignon $P$, Sinigaglia F, D'Ambrosio D (2001) Unique chemotactic response profile and specific expression of chemokine receptors CCR4 and CCR8 by CD4(+)CD25(+) regulatory $\mathrm{T}$ cells. J Exp Med 194:847-853

27. Hirahara K, Liu L, Clark RA, Yamanaka K, Fuhlbrigge RC, Kupper TS (2006) The majority of human peripheral blood CD4 + CD25highFoxp3 + regulatory T cells bear functional skinhoming receptors. J Immunol 177:4488-4494

28. Baatar D, Olkhanud P, Sumitomo K, Taub D, Gress R, Biragyn A (2007) Human peripheral blood T regulatory cells (Tregs), functionally primed CCR4 + Tregs and unprimed CCR4- Tregs, regulate effector T cells using FasL. J Immunol 178:4891-4900

29. Curiel TJ, Coukos G, Zou L, Alvarez X, Cheng P, Mottram P, Evdemon-Hogan M, Conejo-Garcia JR, Zhang L, Burow M, Zhu Y, Wei S, Kryczek I, Daniel B, Gordon A, Myers L, Lackner A, Disis ML, Knutson KL, Chen L, Zou W (2004) Specific recruitment of regulatory $\mathrm{T}$ cells in ovarian carcinoma fosters immune privilege and predicts reduced survival. Nat Med 10:942-949

30. Yano H, Ishida T, Inagaki A, Ishii T, Ding J, Kusumoto S, Komatsu H, Iida S, Inagaki H, Ueda R (2007) Defucosylated anti CC chemokine receptor 4 monoclonal antibody combined with immunomodulatory cytokines: a novel immunotherapy for aggressive/ refractory mycosis fungoides and Sezary syndrome. Clin Cancer Res 13:6494-6500

31. Nadali G, Tavecchia L, Zanolin E, Bonfante V, Viviani S, Camerini E, Musto P, Di Renzo N, Carotenuto M, Chilosi M, Krampera M, Pizzolo G (1998) Serum level of the soluble form of the CD30 molecule identifies patients with Hodgkin's disease at high risk of unfavorable outcome. Blood 91:3011-3016

32. Zinzani PL, Pileri S, Bendandi M, Buzzi M, Sabattini E, Ascani S, Gherlinzoni F, Magagnoli M, Albertini P, Tura S (1998) Clinical implications of serum levels of soluble CD30 in 70 adult anaplastic large-cell lymphoma patients. J Clin Oncol 16:1532-1537

33. Younes A, Consoli U, Snell V, Clodi K, Kliche KO, Palmer JL, Gruss HJ, Armitage R, Thomas EK, Cabanillas F, Andreeff M (1997) CD30 ligand in lymphoma patients with CD30 + tumors. J Clin Oncol 15:3355-3362

34. Snanoudj R, Rouleau M, Bidère N, Carmona $S$, Baron C, Latinne D, Bazin H, Charpentier B, Senik A (2004) A role for CD2 antibodies (BTI-322 and its humanized form) in the in vivo elimination of human $\mathrm{T}$ lymphocytes infiltrating an allogeneic human skin graft in SCID mice: an Fcgamma receptor-related mechanism involving co-injected human NK cells. Transplantation 78:50-58

35. Zhang Z, Zhang M, Ravetch JV, Goldman C, Waldmann TA (2003) Effective therapy for a murine model of adult T-cell leukemia 
with the humanized anti-CD2 monoclonal antibody, MEDI-507. Blood 102:284-288

36. Zhang Z, Zhang M, Goldman CK, Ravetch JV, Waldmann TA (2003) Effective therapy for a murine model of adult T-cell leukemia with the humanized anti-CD52 monoclonal antibody, Campath-1H. Cancer Res 63:6453-6457

37. Zhang M, Zhang Z, Garmestani K, Goldman CK, Ravetch JV, Brechbiel MW, Carrasquillo JA, Waldmann TA (2004) Activating $\mathrm{Fc}$ receptors are required for antitumor efficacy of the antibodies directed toward CD25 in a murine model of adult T-cell leukemia. Cancer Res 64:5825-5829

38. Moretta L, Bottino C, Pende D, Mingari MC, Biassoni R, Moretta A (2002) Human natural killer cells: their origin, receptors and function. Eur J Immunol 32:1205-1211

39. Niwa R, Hatanaka S, Shoji-Hosaka E, Sakurada M, Kobayashi Y, Uehara A, Yokoi H, Nakamura K, Shitara K (2004) Enhancement of the antibody-dependent cellular cytotoxicity of low-fucose IgG1 is independent of FcgRIIIa functional polymorphism. Clin Cancer Res 10:6248-6255

40. Zou W (2006) Regulatory T cells, tumor immunity and immunotherapy. Nat Rev Immunol 6:295-307

41. Zou W (2005) Immunosuppressive networks in the tumor environment and their therapeutic relevance. Nat Rev Cancer 5:263-274
42. Finn OJ (2008) Cancer immunology. N Engl J Med 358:27042715

43. Hodi FS, Butler M, Oble DA, Seiden MV, Haluska FG, Kruse A, Macrae S, Nelson M, Canning C, Lowy I, Korman A, Lautz D, Russell S, Jaklitsch MT, Ramaiya N, Chen TC, Neuberg D, Allison JP, Mihm MC, Dranoff G (2008) Immunologic and clinical effects of antibody blockade of cytotoxic T lymphocyte-associated antigen 4 in previously vaccinated cancer patients. Proc Natl Acad Sci USA 105:3005-3010

44. Maker AV, Yang JC, Sherry RM, Topalian SL, Kammula US, Royal RE, Hughes M, Yellin MJ, Haworth LR, Levy C, Allen T, Mavroukakis SA, Attia P, Rosenberg SA (2006) Intrapatient dose escalation of anti-CTLA-4 antibody in patients with metastatic melanoma. J Immunother 29:455-463

45. Sanderson K, Scotland R, Lee P, Liu D, Groshen S, Snively J, Sian S, Nichol G, Davis T, Keler T, Yellin M, Weber J (2005) Autoimmunity in a phase I trial of a fully human anti-cytotoxic T-lymphocyte antigen-4 monoclonal antibody with multiple melanoma peptides and Montanide ISA 51 for patients with resected stages III and IV melanoma. J Clin Oncol 23:741-750

46. Bryceson YT, March ME, Ljunggren HG, Long EO (2006) Synergy among receptors on resting NK cells for the activation of natural cytotoxicity and cytokine secretion. Blood 107:159-166 